\title{
Organizational Culture in Serbian Companies According to the Denison Model
}

\author{
Snežana Kirin $^{1}$ | Gordana Gavrić ${ }^{2 *}$ | Sandra Kirin ${ }^{3}$ \\ 1 University of Belgrade, Innovative Center of Faculty of Mechanical Engineering \\ 2 Faculty of Business Economics and Entrepreneurship, Department for Management \\ ${ }^{3}$ Statistical Office of the Republic of Serbia
}

\begin{abstract}
The phenomenon of organisational culture is an important source of competitiveness of today's organisations, and therefore, organisational culture is an important research topic of modern management science. Finding the balance between diametrically opposite requirements, for stability and flexibility, is a challenge in managing organisations in a modern business environment. These requirements are incorporated into Denison's model of organisational culture, applied in this research on companies in Serbia. According to the Denison model, organisational stability factors are its mission and consistency, while factors that characterise its flexibility are the organisation's adaptability and the involvement of employees. A well-formulated mission with which all employees are familiar makes the organisation unique on the path to achieving the desired goal. Consistence that relates to a well-defined system of values and rules facilitates resolving conflicts and other problems in the day-to-day functioning of the organisation. On the other hand, organisations with high participation of employees are more efficient and more likely to implement changes, while the ability to quickly and adequately adapt to challenges from the environment allows organisations to preserve their competitiveness on the market. The obtained results of the research showed that there is a balance of the factors of stability and flexibility, which according to the model is a welcomed result, but also that there is a significant place for improvements in the organisational culture. The results presented in this paper may serve as useful information for policymakers to plan changes that improve business efficiency.
\end{abstract}

Key words: organisation culture, Denison Model, mission, the involvement of employees, consistency, adaptability, Serbian companies

JEL Classification: M14

\section{INTRODUCTION}

Today's business environment is marked by the fourth industrial revolution characterised by the growing demand for connectivity, communication and networking, automation, digitisation, flexibility, "smart" management, ecology, and social responsibility. Complex business conditions increase business risk and the importance of organisational culture, which permeates all the activities of organisations, becomes more and more prominent. "Due to the complexity of the human factor in the company, it takes a lot of expertise and relevant skills to successfully guide people's behaviour in accordance with the strategy and goals of the company" (Kirin, Mitrovic, Borovic \& Sedmak, 2016, p. 825).

\footnotetext{
${ }^{*}$ Corresponding author, e-mail: gordana.gavric@vspep.edu.rs
} 
Despite a number of works dealing with the organisational culture, there is no unique definition and tools for its measurement. According to Edgar H. Schein, organisational culture means "a pattern of shared basic assumptions learned by a group as it solved its problems of external adaptation and internal integration (...), and it is a product of joint learning"(Schein, 2013). Janicijevic states that "organizational culture is defined as a system of assumptions, values, norms, and attitudes, manifested through symbols which the members of an organization have developed and adopted through mutual experience and which help them determine the meaning of the world around them and how to behave in it" (Janicijevic, 2012, p. 25). In short, organisational culture is a powerful force that holds together members of an organisation (Janicijevic \& Milovanovic, 2015) giving it uniqueness, and the fact that it is invisible and intangible makes it a real puzzle for imitators and competitors.

"Organizational culture like "operating system" leads an organisation and its activities, shaping the way its employees think, work, and how they feel"(Vukotic, Sukovic, Rasevic, Maksimovic \& Goati, 2014, p. 406).

Organisational culture establishes value systems. If we want a "culture to be a "tailwind" to business success, there has to be compliance between organisation's management principles and its organisational culture"(Gavric, Sormaz \& Ilic, 2016, p. 28). Stone D.L. and all considered "the impact that values may have on (a) the establishment of performance criteria, (b) the methods used to measure" (Stone, Stone-Romero \& Lukaszewski, 2007, p. 160).

According to J. Chatman and C. O'Reill, to make progress "future research should focus on conceptualizing and assessing organizational culture as the norms that characterize a group or organization that if widely shared and strongly held, act as a social control system to shape members' attitudes and behaviours"(Chatman \& O'Reill, 2016, p.199).

"Alvesson \& Sveningsson, 2015; Katzenbach, Steffen, \& Kronley, 2012; Lorsch \& McTague and others stated that managers have also recognised the importance of culture because of the presumed relationship between certain types of organisational cultures and effective organisational performance" (Chatman \& O'Reill, 2016, p.202). An example of this is the company Chrysler which, after struggling for survival, accepted the change of culture, involving employees in the entire process, focusing on learning and "put emphasis on quality and they once again, became a successful and profitable company" (Krouse, 2012, p. 28).

"Today, it is clear to almost all managers that the key to long-term success lies not in individual strategies and effective management of resources, but in, so far largely neglected dimension of governance, the cultural dimension" (Cardona \& Ray, 2009, p. 32). In other words, "in order to understand the source of competitive advantage of a company, one must understand its organisational culture" (Janicijevic, 1997, p. 23). According to Korn Ferry survey in July 2014, with more than 500 global respondents, "72 per cent said they feel culture is extremely important to organisational performance, but only 32 per cent said their organisational culture aligns to a great extent with their business strategy. The survey also showed that despite the high ranking in importance, only 25 per cent believe they have identified and communicated their culture to a great extent, and only 35 per cent believe their employees are able to articulate their culture to a great extent" (Eaton \& Kilby, 2015, p. 5).

Recognising the importance of organisational culture problem in Serbia, the authors did extensive research using the Denison Model based on following factors of organisational culture: mission, employee involvement, consistency and adaptability (Denison \& Mishra, 1995), which also allows displaying a degree of each dimension appliance. This model is chosen because it is generally applicable and it balances the need for stability of a company, represented by its mission dimensions and consistency as well as the need for flexibility, represented by employee involvement and adaptability. The aim of the conducted research is to point out critical aspects of the organisational culture whose improvement will improve the efficiency and competitive advantage of the Serbian companies, and the conclusions will serve as useful information for decision makers to make better decisions. 


\section{FACTORS OF ORGANIZATION CULTURE ACCORDING TO DENISON MODEL}

"A mission is an important aspect of organisational culture. Unclear missions, as an image or label, or its absence results in the company being left at the mercy of market forces"(Gavric, Sormaz \& Ilic. 2016, p. 28). Mission differentiates the company in relation to its competitors, fueling sharing of values that brings business success and competitive advantage to an organisation.

The behaviour produced by the mission should lead an organisation to significant financial results, not to its exerting of a mission formulation.

Consistency is reflected by the presence of stability, which implies well-defined value and a system as the foundation of a strong organisational culture. Sharing key values and expectations among employees will facilitate the resolution of disputes and other efforts in an organisation functioning.

Lamberg J. A. states that, although "flexibility and speed are considered sources of competitive advantage in a dynamic environment, researches of development strategies see consistency as a necessary condition for company survival (e.g. Barnett \& Hansen, 1996; Sheth \& Sisodia, 2002)(Lamberg, Tikkanen, Nokelainen \& Suur-Inkeroinen, 2005)”(Gavric \& Stankovic, 2015, p. 132). "Using established business practices, a company develops efficient processes and routines that support its long-term goals and strategies through knowledge that the organisation remains independent of the departure of individual" (Gavric \& Stankovic, 2015, p.132).

Unlike traditional hierarchical organisations, which tend to have standard policies and procedures when dealing with certain issues, organisations with high employee involvement can make more effective decisions on specific environmental problems or special customers' requirements, but also have a chance to be more flexible and faster in their decision making (Lawler, 1993). Also, changes will be easier to introduce if the power of attorney concept and employee involvement is already developed.

Jovanovic states that "failures in organisational learning also limit organisational adoption and ability to change" (Jovanovic, 2015, p. 147). He examined "one of the most important organisational learning issues, the distinction between lower-level learning and higher-level learning. Lower-level learning is characterized by improvements or refinements of existing beliefs, understandings, and organisational processes. Higher-level learning involves developing completely new beliefs, understandings and organisational processes" (Jovanovic, 2015, p. 147).

A perceived need for continuous development of employees is in accordance with the research in which Cvjetkovic stated that 'it is necessary to raise employees' awareness on quality achievement as the factor of business operations improvement. It is of exceptional importance for Serbian companies to realize that it is necessary to change the way and the philosophy of business operations in the future" (Cvjetkovic, 2015, p. 69).

A danger for the survival of modern companies is their rigidity and a possible decrease in organisational flexibility and resilience. Nowadays, a company's flexibility is the most important factor for its survival, presented by its ability to meet new habits, tastes and needs of consumers and customers, as well as to change the way of treating employees because they want to become important subjects of business by engaging in more decision-making.

Companies that fail to rapidly adjust to the new demands of the global market, would stay behind or taken over by stronger and more successful entrepreneurial players.

By compression of space and time, the process of globalisation exposes workers, companies and states to increasing pressure, imposing fast and efficient adjustment to all stakeholders (Jaksic, 2009). Companies face the challenge to learn and move through this wave of transition as easily and as creatively as possible (Radovic Markovic, 2008). Adequate and timely response in unpredictable business conditions is essential, and a prerequisite for such response of 
management is that employees have a habit of learning, skills and knowledge as well as a desire to learn' (Torrington, Hall \& Taylor, 2004).

"Organizational culture should be cultivated, set in the function of a company's success, but its negative impacts should be avoided" (Gavric, Sormaz \& Ilic, 2016, p.27).

\section{RESEARCHING OF ORGANIZATIONAL CULTURE IN SERBIA USING THE DENISON MODEL}

The questionnaire that was distributed in 2015 was used as the research instrument. The questionnaire was distributed in two ways: personally and via Facebook. It was designed in the form of a Likert scale as that is the most suitable method for evaluating opinions and attitudes. The scale was created in the following way: 1 - completely disagree with the given statement, 2 - partly disagree with the given statement, 3 - neither agree nor disagree with the given statement, 4 - partly agree with the given statement, 5 - completely agree with the given statement. The entire questionnaire was based upon the Denison model (Denison \& Neale, 1999) with the slightest of alternations of the researched statements. The following programs were used for the analysis of the obtained data: IBM SPSS Statistics 21 and MS EXCEL. This paper presents a descriptive statistical data analysis.

A total of 1000 respondents, i.e. employees who came from various companies from twentynine Serbian cities, took part in this research. Tables 1 and 2 describe the personal characteristics of respondents and the companies in which they work.

Table 1. Description of the personal characteristics of the sample

\begin{tabular}{|c|c|c|c|}
\hline & & Frequency & Percentage \\
\hline \multirow{4}{*}{ Gender } & Male & 520 & 52 \\
\hline & Female & 460 & 46 \\
\hline & Missing & 20 & 2 \\
\hline & Total & 1000 & 100 \\
\hline \multirow{5}{*}{ Age } & $18-30$ & 340 & 34 \\
\hline & $31-40$ & 380 & 38 \\
\hline & $41-50$ & 190 & 19 \\
\hline & $41-60$ & 80 & 8 \\
\hline & Over 60 & 10 & 1 \\
\hline \multirow{5}{*}{ Level of education } & High school / highly skilled workers & 420 & 42 \\
\hline & College & 270 & 27 \\
\hline & Faculty & 200 & 20 \\
\hline & Master & 90 & 9 \\
\hline & $\mathrm{PhD}$ & 20 & 2 \\
\hline \multirow{5}{*}{ Years of service } & to 5 & 350 & 35 \\
\hline & $6-15$ & 390 & 39 \\
\hline & $16-25$ & 160 & 16 \\
\hline & $26-35$ & 90 & 9 \\
\hline & over 35 & 10 & 1 \\
\hline \multirow{4}{*}{ Work position } & Worker & 640 & 64 \\
\hline & Low-level manager & 190 & 19 \\
\hline & Middle-level manager & 90 & 9 \\
\hline & Top-level manager & 80 & 8 \\
\hline
\end{tabular}

Source: IBM SPSS Statistics 21 
Table 2. Description of the companies

\begin{tabular}{|c|c|c|c|}
\hline & & Frequency & Percentage \\
\hline \multirow{4}{*}{ Company size } & Micro & 200 & 20 \\
\hline & Small & 171 & 17.1 \\
\hline & Medium & 338 & 33.8 \\
\hline & Large & 291 & 29.1 \\
\hline \multirow{13}{*}{$\begin{array}{l}\text { Company } \\
\text { activity }\end{array}$} & Services & 204 & 20.4 \\
\hline & $\begin{array}{l}\text { Public administration and mandatory } \\
\text { social security }\end{array}$ & 178 & 17.8 \\
\hline & Production & 140 & 14 \\
\hline & Education & 116 & 11.6 \\
\hline & Finance and insurance & 84 & 8.4 \\
\hline & Transportation and storage & 66 & 6.6 \\
\hline & Lodging and meals & 47 & 4.7 \\
\hline & Health and social care & 43 & 4.3 \\
\hline & Information and communication & 39 & 3.9 \\
\hline & $\begin{array}{l}\text { Administrative and support service } \\
\text { activities }\end{array}$ & 36 & 3.6 \\
\hline & $\begin{array}{l}\text { Professional, scientific and technical } \\
\text { activities }\end{array}$ & 26 & 2.6 \\
\hline & Arts, entertainment and recreation & 19 & 1.9 \\
\hline & Real estate services & 2 & 0.2 \\
\hline \multirow{2}{*}{$\begin{array}{l}\text { Company } \\
\text { ownership }\end{array}$} & Domestic & 860 & 86 \\
\hline & Foreign & 140 & 14 \\
\hline \multirow{3}{*}{$\begin{array}{l}\text { Ownership } \\
\text { structure }\end{array}$} & Private & 520 & 52 \\
\hline & State-owned & 440 & 44 \\
\hline & Public & 40 & 4 \\
\hline
\end{tabular}

Source: IBM SPSS Statistics 21

\section{Exploring the Mission Dimension}

For the MISSION testing, the following statements were observed:

- "There is a long-term purpose of the company existence as well as its development direction",

- "Our strategy leads other organisations to change the way they compete in the industry",

- "There is a clear mission that gives meaning and direction to our work",

- "There is a clear strategy for the future",

- "Our strategic direction is clear to me",

- "Leaders set goals that are ambitious, but realistic",

- "There is widespread agreement about goals",

- "The leadership has "gone on record" about the objectives we are trying to meet",

- "We continuously track our progress against our stated goals",

- "People understand what needs to be done for us to succeed in the long run",

- "We have a common vision of what the organisation will be like in the future",

- "Short-term thinking seldom compromises our long-term vision",

- "Leaders have long-term thinking",

- "Our vision creates excitement and motivation for our employees", 
- "We are able to meet short-term demands without compromising our long-term vision"(Denison \& Neale, 1999, p. 2-14-2-15)

Mean values for compliance with the preceding paragraphs are shown in Figure 1. The figures will show only key words of the statements.



Figure 1. Results on the mission

Source: MS EXCEL

The results showed that the mean value of the compliance with the individual positions varied between grades 3 and 4, i.e. between the neither agree nor disagree and the partially agree scale measures concerning the researched statements. The overall mean is 3.56.

A minimum value of the mean compliance is reported in relation to the following statements:

- "Our vision creates excitement and motivation for our employees" (3.14)

- "We have a common vision of what the organisation will be like in the future" (3.28)

- "Short-term thinking seldom compromises our long-term vision" (3.32)

The greatest values of the mean compliance are reported related to the following statements:

- "There is a long-term purpose of the company existence as well as its development direction" (3.99)

- "There is a clear mission that gives meaning and direction to our work" (3.88)

- "Our strategic direction is clear to me" (3.76)

The strongest factors related to the dimension of mission defined in the Denison Model are strategy, goals, and vision. In addition to these factors, the experience of employees, company size and position in it, ownership of the company (and the fact whether it is domestic or foreign), level of education, employee activity as well as social environment also influence mission understanding of enterprises in Serbia. 


\section{Exploring consistency dimension}

The following statements are considered:

- "The leaders and managers do what they say",

- "There is a characteristic management style and a distinct set of management practices",

- "There is a clear and consistent set of values that governs the way we do business",

- "Ignoring core values will get you in trouble",

- "There is an ethical code that guides our behaviour and tells us right from wrong",

- "When disagreements occur, we work hard to achieve "win-win" solutions",

- "There is a "strong" culture",

- "It is easy to reach consensus, even on difficult issues and key issues",

- "There is a clear agreement about the right way and the wrong way to do things",

- "Our approach to doing business is very consistent and predictable",

- "People from different parts of the organisation share a common perspective",

- "It is easy to coordinate projects across different parts of the organisation",

- "Working with someone from another part of this organisation is not like working with someone from a different organisation",

- "There is good alignment of goals across levels" (Denison \& Neale, 1999, p. 2-10-2-11)

Mean values for compliance with the previous statements are shown in Figure 2.

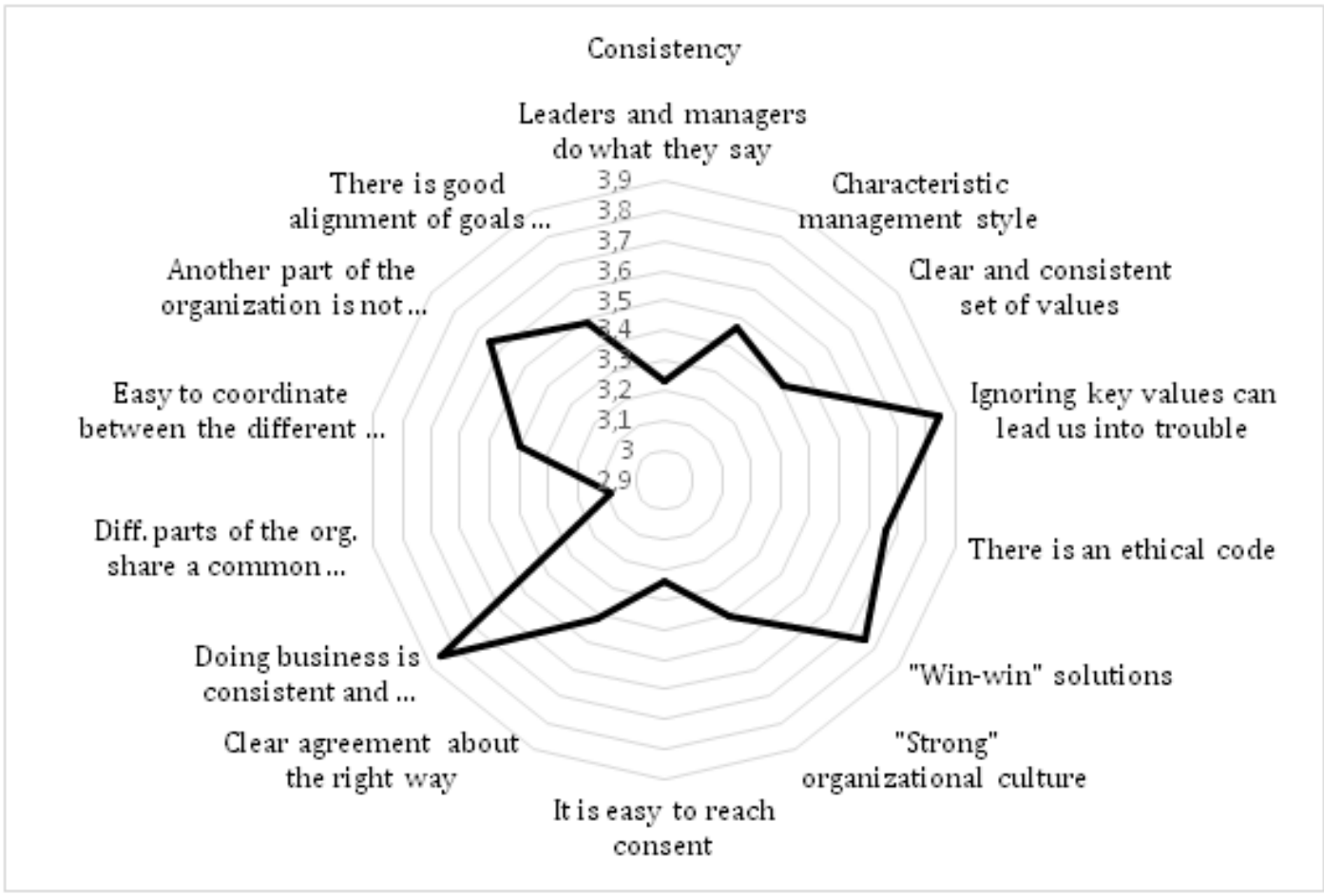

Figure 2. Results of consistency

Source: $M S$ EXCEL

The results of the analysis of compliance with the views of the consistency show that all the answers are in the interval between 3 and 4, i.e. between the neither agree nor disagree and the 
partially agree scale measures concerning the researched statements. The minimum obtained value is related to the statement that all employees have equal chances and opportunities for promotion ("People from different parts of the organization share a common perspective" (Denison \& Neale, 1999, p. 2-10)) - it is the closest to the value: neither agree nor disagree, while the closest value 4- partly agree (3.85) is related to the statement: "Ignoring core values will get you in trouble"(Denison \& Neale, 1999, p. 2-10). Lower values are related to the following statements:

- "People from different parts of the organisation share a common perspective" (3.08)

- "The leaders and managers do as they say" (3.23)

- "It is easy to reach consensus, even on difficult issues and key issues" (3.24)

- "It is easy to coordinate projects across different parts of the organisation" (3.39)

The main factors of consistency by the Denison Model are defining core values and business ethics in an organisation and their implementation in dealing with co-workers, clients and all interested parties in order to reach agreements and management coordination. In organisations with strong consistency, employees understand a 'big picture' without creating obstacles to goal achievement.

An experience, organisation size, an employee's position in it, the culture of an organisation, i.e. domestic or foreign ownership, gender, company activity and social environment where a company is located also influence attitudes towards consistency.

\section{Exploring dimensions of employee involvement}

Aspects of employee involvement have been seen through empowerment, personal development and team orientation. In terms of transitional changes, employee involvement contributes to a faster and more successful acceptance and implementation of the necessary modifications.

The following statements were observed:

- "Most employees are highly involved in their work",

- "Decisions are usually made at the level where the best information is available",

- "Information is widely shared so that everyone can get the information he or she needs when it's needed",

- "Everyone believes that he or she can have a positive impact",

- "Business planning is ongoing and involves everyone in the process to some degree",

- "Cooperation across different parts of the organisation is actively encouraged",

- "People work like they are part of a team",

- "Teamwork is used to get work done, rather than hierarchy",

- "Teams are our primary building blocks",

- "Work is organised so that each person can see the relationship between his or her job and the goals of the organisation",

- "Authority is delegated so that people can act on their own",

- "There is a continuous investment in the skills of employees",

- "The capabilities of people are viewed as an important source of competitive advantage",

- "Problems seldom arise because we have the skills necessary to do the job"(Denison \& Neale, 1999, p. 2-8-2.9)

Mean values for compliance with the previous statements are shown in Figure 3. 


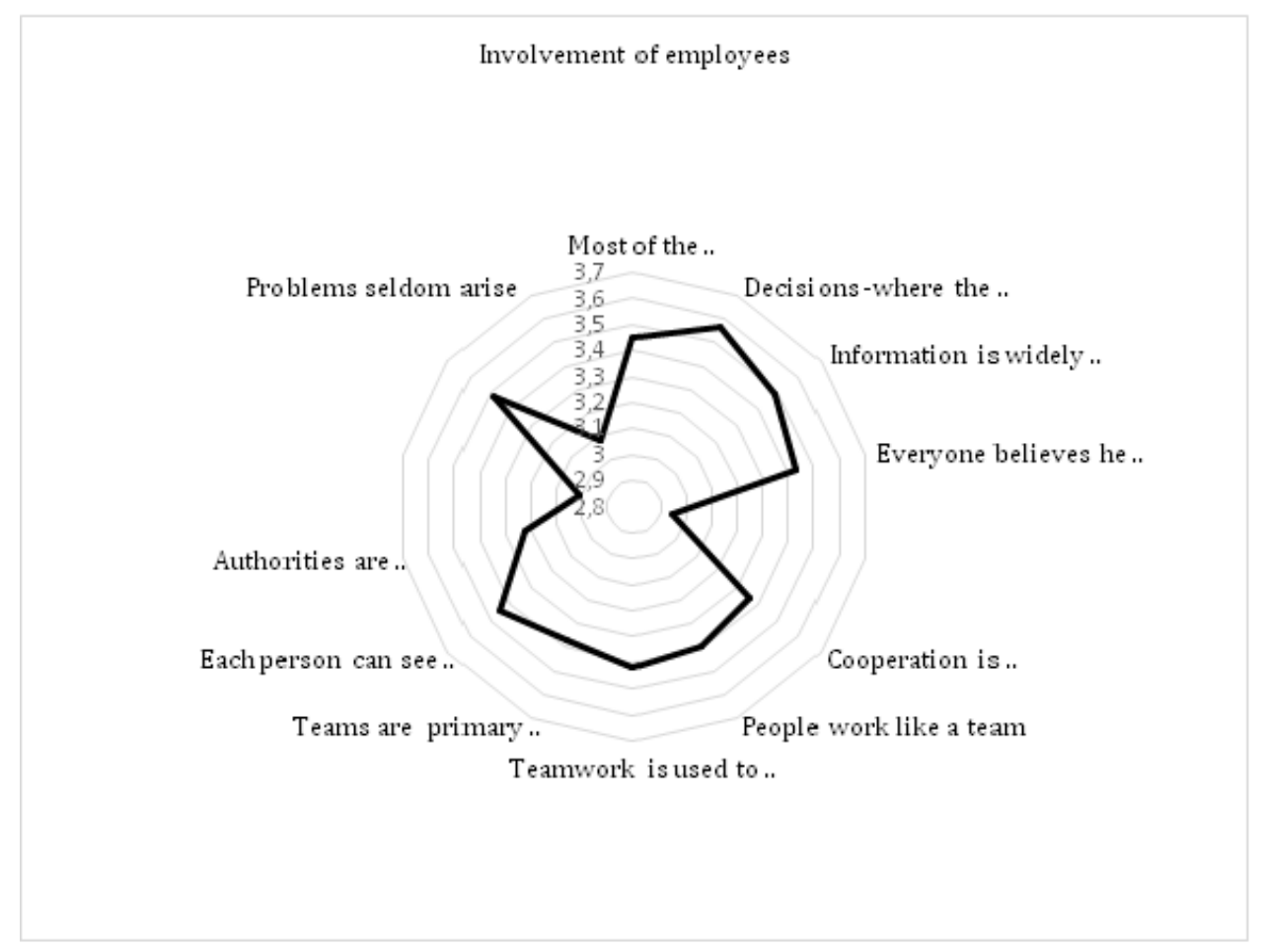

Figure 3. Results for employee involvement

Source: $M S$ EXCEL

The result shows that employees are the least involved in the planning process (mean $=2.95$ ) and they disagree with the statement that they rarely face problems because they have all the skills needed for the job (mean $=3$ ). Values of approvals given by the respondents along with the other statement vary between 3 and 3.5, i. e. around the neutral position. The results show that there is no value close to 4 in any statement describing employee involvement, which is in correspondence with the statement.

The maximum value is obtained in the statement that decisions are made where the best information are obtained so that it can be interpreted by the importance of the decision-making process.

It can be said that the following was observed:

- Small influence of employees on business policy creating and

- A need for continuous development of employees.

The study of employee involvement showed that obtained factors were identical to involvement factors in the Denison Model: teamwork, professional development and empowerment (through access to information and decision-making where the information are available).

\section{Exploring the adaptability dimension}

The following statements were examined:

- "The way things are done is very flexible and easy to change",

- "We respond well to competitors and other changes in the business environment",

- "New and improved ways to do work are continually adopted",

- "Attempts to create change seldom meet with resistance", 
- "Different parts of the organisation often cooperate to create change",

- "Customer wants, and needs are being mentioned and have directly influence on decisions and business",

- "We encourage direct contact with customers by our people",

- "We view failure as an opportunity for learning and improvement",

- "Innovation and risk-taking are encouraged and rewarded",

- "Learning is an important objective in our day-to-day work",

- 'We are familiar with the work of other sectors at all times"(Denison \& Neale, 1999, p. 212-2-13)

Mean values for compliance with the previous statements are shown in Figure 4.

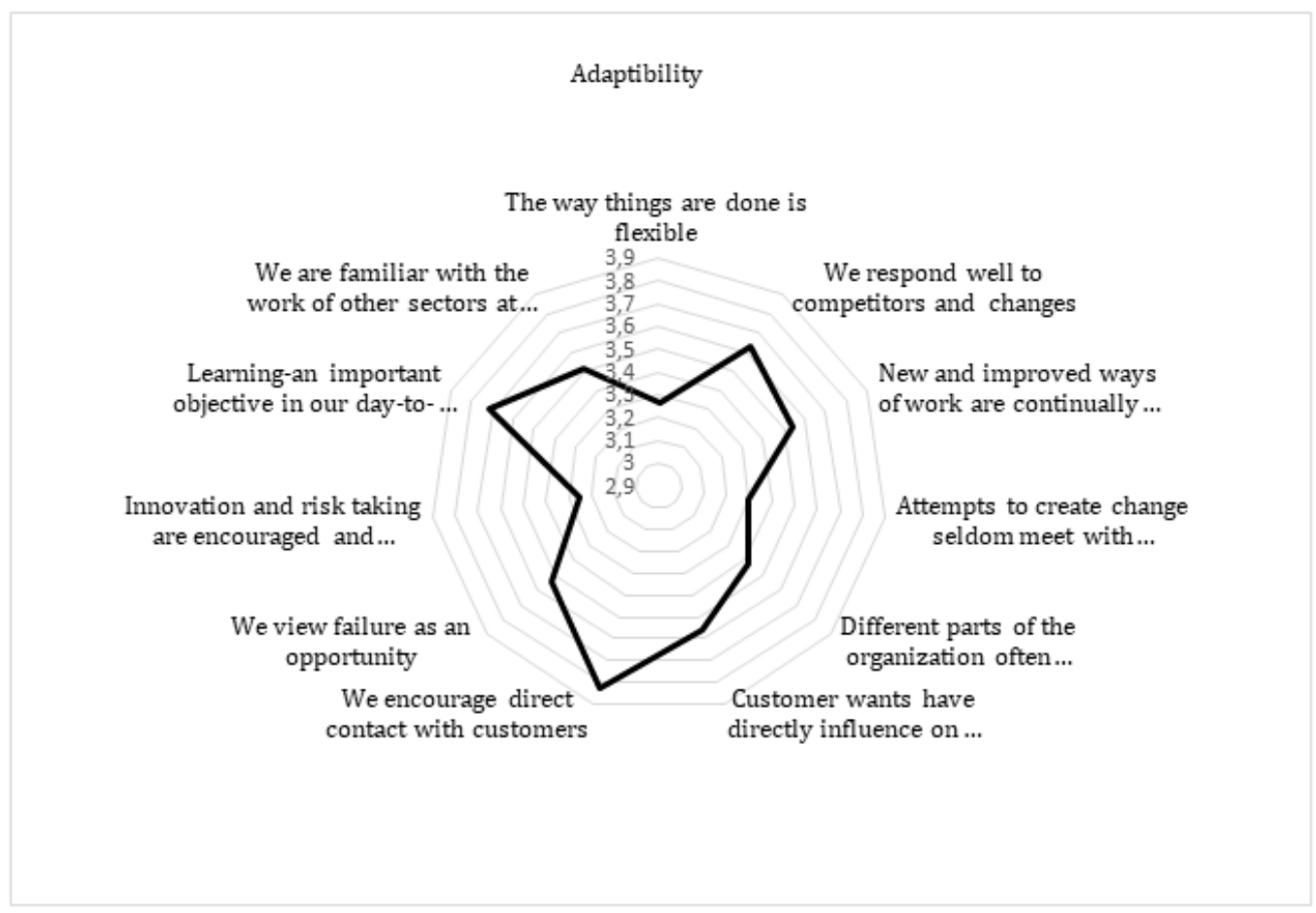

Figure 4. Results on adaptability

Source: $M S$ EXCEL

It may be noted that the minimum value of the compliance degree is related to the following statements:

- "The way things are done is very flexible and easy to change" (3.23)

- "Innovation and risk-taking are encouraged and rewarded" (3.25)

- "Attempts to create change seldom meet with resistance" (3.29).

\section{CONCLUSION}

In order to highlight the values of organisational culture in Serbia, the research has been conducted and presented, using the Denison Model of organisational culture. The research included a sample of 1,000 respondents in enterprises in Serbia, during 2015. Values for all four dimensions of the model have been obtained - mission, consistency, the involvement of 
employees and ability - that vary in the interval from neutral attitude to the attitude "partly agree". This means that the awareness level of the mission is foggy among the staff, consistency dimension is between values "it is both existent and non-existent," employee involvement in the business planning is on a low level, and when it comes to adaptability dimension, there are no concrete measures to stimulate innovation.

By the analysis of organizational culture, we have concluded that the aspects of this culture, the improvement of which will improve the efficiency and competitive advantage of enterprises in Serbia, are: innovation rewarding, investment in continuous employee development, greater influence of employees on the policy and planning of future activities, short-term interests that jeopardize the long-term mission of the company, opportunities and advancement opportunities to all employees, defining a common vision that stimulates and motivates employees with leaders and managers who act in accordance with what they saying and creating a climate in which changes that lead to progress encounter less resistance of employees.

This means that in all dimensions of the observed model, there is room for improvement of the organisational culture in concretised areas, which can serve to policy-makers as useful information for making better decisions. The need for long-term planning that balances shortterm and long-term goals is noted.

The results obtained in 2011 by Nikolic, Savic \& Markoski, regarding organizational culture in companies in Serbia indicated that certain "strategic issues should be improved, such as: quality making strategic decisions, the attitude of the company towards change and innovation, the vision and mission of the company, teamwork, encouraging the creativity of individuals, etc. (Nikolic, Savic \& Markoski, 2011, pp. 649). From this, it can be concluded that the situation in the companies in Serbia has not changed drastically in relation to 2011 and that the critical points are innovation, the vision and the mission and the involvement of employees.

The significance of the research lays in the fact that it has covered a large sample and therefore, it brings an important contribution to the perception of the state of organisational culture in Serbia. The study complements findings reached by researchers who have studied the problem of organizational culture.

Further studies of organisational culture in Serbia should be directed to the application of other general models as well as to the development of specific models for concrete, real situations.

\section{REFERENCES}

Chatman, A. J. \& O'Reill, A. C. (2016).“Paradigm lost: Reinvigorating the study of organizational culture." Research in Organizational Behavior, Vol 36: 199-224.

Cardona, P. \& Rey, C. (2009). Upravljanje pomocu misija. Zagreb: MATE

Cvjetkovic, M. (2015). "Knowledge and quality as the factors of the business operations and competitiveness promotion - research results from Serbia." Industrija, 43 (2): 53- 72.

Denison, D. \& Mishra, A. (1995). "Toward a Theory of Organizational Culture and Effectiveness." Organisation science, 6(2): $204-223$.

Denison, R. D. \& Neale, S. W. (1999). Denison Organizational Culture Survey, Facilitator Guide, http://www.denisonconsulting.com/Docs/DOCS_A-Z/DOCS_Facilitator_Guide.Pdf. Accessed 20.10.2014.

Eaton, D. \& Kilby, G. (2015).“Does Your Organizational Culture Support Your Business Strategy?." The Journal for Quality \& Participation: 4-7.

Gavric, G. \& Stankovic, R. (2015).“The presence of factor of stability in organizations culture of organizations in Serbia." 4. International Scientific Conference "Employment, education and entrepreneurship", Faculty of Business Economics and Entrepreneurship, Belgrade, Serbia: $129-146$ 
Gavric G., Sormaz G. \& Ilic Đ. (2016). "The impact of organizational culture on the ultimate performance of a company." International Review, 3-4: 25-30

Jaksic, M. (2009). "Svetski system I globalizacija." Godišnjak Fakulteta za kulturu i medije: komunikacije, mediji, kultura, number 1: 239-256.

Janicijevic, N. (2012). "The Relationship between Organizational Culture and Organizational Strategy." Economic annals, LVII (193): 25-51.

Janicijevic, N. (1997). Organizaciona kultura: kolektivni um preduzeca. NoviSad: ULIXES, Belgrade: Faculty of economics

Janicijevic, N. \& Milovanovic, M. (2015). "The impact of information and communication technology on decentralization: the role of organizational culture." Ekonomika preduzeca, 3-4: 171-181.

Jovanovic, Z. (2015). “Management and changes in business environment." Ekonomika, 61 (2): 143-151.

Kirin, S., Mitrovic, M., Borovic, S. \& Sedmak, A. (2016). "Impact of the life cycle of company to job satisfaction." Technical gazette, 23 (3): 819-825.

Krouse, H. (2012). "Organization culture and entrepreneurship”. International Review, No 3-4: 27- 33.

Lamberg, J.A., Tikkanen, H., Nokelainen, T. \& Suur-Inkeroinen, H. (2005). "Competitive Dynamics, Strategic Consistency and Organizational Survival." ForthcomingStrategic Management Journal: 1- 32.

Lawler, E.III. (1993). Creating the high-involvement organization; Organizing for the future. San Francisco: Jossey- Bass Publisher.

Nikolic, M., Savic, M. \& Markoski, B. (2011). "Research of individual organizational culture parameters in Serbian enterprises". Tehnika, 66 (4): 643-650.

Radovic Markovic, M. (2008). “Effective organizational change management.” Serbian Journal of Management,3 (1): 119 - 125.

Schein, E. (2013). Organizational Culture and Leadership, Accessed 22.09.2018.https://thehypertextual.com/2013/01/17/edgar-schein-organizational-cultureand-leadership/

Stone, L. D., Stone-Romero, E. F., \& Lukaszewski, K. M. (2007). “The impact of cultural values on the acceptance and effectiveness of human resource management policies and practices." Human Resource Management Review,17: 152-165.

Torrington, D., Hall, L. \&Taylor S. (2004). Menadzment ljudskih resursa. Belgrade: Data Status

Vukotic, V., Sukovic, D., Rasevic, M., Maksimovic, S. \& Goati, V. (2014). (Anti)liberalizam i ekonomija. Belgrade: Center for Economic Research of Institute of Social Sciences

Article history: $\quad$ Received: November 29, 2018

Accepted: May 26, 2019 